from dismissing, has actually confirmed many of the historical sites described in the Bible. As to the artefacts-some peoples' hearts must still be in the right place judging by the money forthcoming and the technical skill demonstrated which together have accomplished the costly and immensely difficult task of restoring York Minister. And what about Coventry Cathedral? The problems of pollution, overpopulation, and famine are being tackled as never before, while the problem of nuclear weapons has stimulated more responsibility in their handling than I would have thought possible. Far from making us omnipotent, it is these very weapons and their power which makes some of us realize how insignificant we are.

As regards medicine, of course science is helpful—partly by cutting the birth rate. We know of the problems of cigarettes and lung cancer, but preventive medicine has always been unpopular. There will always be doctors who beef about conditions and, much as we would like to forget it, cashnecessary so long as we must pay our way. As regards foreign doctors in our hospitals, let us never forget the many British doctors serving in foreign (mission) hospitals.

Is Christianity really as meaningless and void as Dr. Bradshaw would have us believe? Each challenge must be met and tackled in a spirit of hope, for it will do no good to despair.-I am, etc.,

Bexhill-on-Sea, Sussex

GRAHAM HUNTER

\section{Economies in the N.H.S.}

SIR,-For many years the "sterile" water supplied for use in lotion bowls in our operating theatres has been prepared locally at very little cost. In recent months the Department of Health has specified that this water should be particle-free and this has made it necessary for us to purchase sterile water from a commercial source at a cost of $£ 30,000$ per year for our district alone.

We believe that a distinction should be made between lotions for intravenous administration, which must of course be particle-free, and lotions for washing gloves and preparing moist packs in the operating theatre, which we believe to be safe provided they are sterile.

Every possible economy must be made if our Health Service is to run efficiently, and it makes us angry to see money needlessly spent while essential maintenance and capital schemes are curtailed.-We are, etc.,

Patrick SAMEs THEO SCHOFIELD HOWELL JOHN K. LLOYD WILLIAMS W. F. W. SOUTHWOOD Clive Charlton Royal United Hospital, Patrick SMith Bath

\section{New N.H.S. Management}

SIR,-As an administrator I was interested to see the letter from Dr. M. Goldman (21 September, p. 745). There is a strong body of opinion among administrators that would agree with Dr. Goldman that the reorganization of the N.H.S. has introduced one layer of management too many and the sooner either the regional or area tier is removed the better.

I am sure that many doctors will be pleased to know that the Department of Health and Social Security has recently imposed a fairly severe restriction on the number of senior and middle-graded administrators that may be appointed in each region. It would be most unfortunate if the creation of regional and area levels resulted in inadequate numbers of the above administrators at district level. Great emphasis has been placed on the importance of the district as the cperational and health care planning level. It is at this level that administrators can provide the greatest amount of help and support to their medical, nursing, and other colleagues.

As we are compelled to have regional and area tiers at present, it is vital that they should not become bureaucracies containing large numbers of administrators, appearing to hinder rather than aid the smooth running and development of the operational level where the majority of administrative work should take place in close co-operation with colleagues from all disciplines in the Health Service.-I am, etc.,

\section{R. I. SPENCER}

Birmingham

\section{Doctors' Pay}

SIR,-In the past year or so your correspondence columns have contained letters from general practitioners and hospital specialists about the poor terms and conditions of service for doctors within the Health Service. Many of these letters highlight the inequalities that exist in the mode and level of payments of doctors in various parts of the Service.

I beg the courtesy of your columns ance again to comment more generally on our problems. Those like myself in whole-time hospital practice feel especially badly treated. It is, however, petty and divisive constantly to compare our lot with that of others. Nobody in N.H.S. medicine is adequately paid today. The general practitioners, who are doing rather better than the specialists, are certainly not overpaid. It needs to be recognized that the whole pyramidal pay structure of doctors has slipped in relation to other groups both in the Health Service and outside. As we are employed by a monopoly employer, the Government, it is supremely difficult for our negotiators to establish a yardstick for our pay structure, as there is nothing outside the N.H.S. with which to compare. It would be very interesting to know how the pyramidal pay structures of doctors in European countries was related to the pay of other professional and non-professional groups as compared with Britain. Under the present circumstances only the doctors can decide what they are worth and I believe we should do this and state it very clearly.

In addition, our other problem is the failure of our organizations to present our true situation to the public, who regard all doctors, and hospital specialists in particular, as rich and powerful. My own experience indicates that the popular conception of a doctor's material well-being is so far ahead' of the truth that it is difficult to convince all but one's most intimate non-medical friends of the facts. It would seem that the B.M.A. could, with profit, make some effort to acquaint the public with the real facts. We might then have some popular support. -I am, etc.

R. D. H. RYall

Mersey Regional Centre for Radiotherapy and

Oncology,

Chatterbridge Hospital West,

Bebington, Wirral,

Merseyside

\section{Trade Union Tactics}

SIR,-I must endorse Dr. P. E. Baldry's plea for unity within the profession at this time (21 September, p. 744). However, the British Medical Association represents all the factions which Dr. Baldry has listed and it would seem to be a more simple solution for all of the profession to come together and rally behind the major medicopolitical organization.

I would therefore appeal to those who have resigned to rejoin and to those who have not been members of the Association to join it. The Association can ill afford the loss of more radical practitioners, which only intensifies the excessively conservative nature of the B.M.A., which in turn arises from the excessively conservative nature of medical practitioners. When these more radical practitioners have joined the B.M.A. they should then lobby their proposals through the machinery so that they may influence the total policy of the Association. This is best done at the local division level as the local division has the facility to forward resolutions to the annual policymaking meeting of the Representative Body. If any member is unable to locate his local division he may get the name and address of the local honorary secretary from B.M.A. headquarters.

The appointment of a professional trade union experienced negotiator (non-medical) to the B.M.A. team of negotiators might well derive from such active lobbying. It has been not adopted in the past only because it seems that the majority of the profession do not want it.-I am, etc.,

Hanworth, Middlesex

DERMOT LYNCH

\section{N.H.S. Contraceptive Services}

SIR,-At last there are signs of common sense breaking through with the Family Planning Association chief medical officer's plan for nurses to repeat prescriptions for the pill. ${ }^{1}$ Many will agree with his forecast that within the next decade the pill will be on open sale.

"Money for old rope" is my view as a general practitioner of the present B.M.A. recommended rate of $£ 1.56$ for the yearly private pill prescription. The exorbitant demands of our negotiators are slowly pricing us out of the market. The only professional skill required in most cases is on the initial visit, when a few minutes' history can be taken at the same time as blood pressure reading and pelvic and breast examination. Follow-up blood pressure checks, cervical smears, and breast examination can be undertaken by a competent practice nurse. I give my patients credit for the intelligence to report any side effects and find they are not slow to come forward. 
Unless we settle soon for a reasonable fee, which I personally feel is near the one offered, then we shall soon lose one of our most lucrative "perks" along with, in many cases, the fees for quinquennial cervical smears.-I am, etc.,

Burnham, Bucks

ROBERT GREEN

1 Guardian, 24 September 1974, p. 5.

\section{Purchase of Added Years}

SIR,-I am disturbed by the N.H.S. pamphlet on "Purchase of Added Years" (S.D.S.) to which the chairman of the B.M.A. Superannuation Committee seems to give some importance and suggests consulting our accountants to see if there is any advantage in the contents $(7$ September, p. 630).

The whole premise of this pamphlet is the ridioulous one that a doctor has to put in 40 years' service by the age of 60 . (What trade union would countenance that?) I should have thought that the Association would reject the fatuous and impossible ruling and therefore refuse to have anything to do with this product of long gestation on which a rapid reply is expected.

It must be insisted that 30 years in the Health Service during which practitioners are responsible for night and day care for the patient is a more than adequate term for full pension rights. Because of this we should not give tacit recognition of an unattainable rule foisted on us by the administrative mind.

As a bitter postscript my annual net practice income, before car expenses and tax, as a senior partner with an increasing list has risen by approximately $£ 300$ since October 1972 and it is probably unlikely that purchase at a later date would make much difference if I did accept the thinking behind the pamphlet.-I am, etc.,

Luton

ANDREW JACKSON

\section{Annual Postgraduate Meeting}

SIR,-After 30 years of membership of the B.M.A. I have just attended my first Annual Postgraduate Meeting and realize what I have missed over the years. My wife and I have just had a very pleasant three days in the Isle of Man, in good company, and the Scientific Meeting was most stimulating.

I look forward to the next opportunity to attend a similar function and would strongly recommend these meetings to all other members.-I am, etc.,

Bristol

P. A. TRAFFORD

\section{Royal Medical Benevolent Fund Christmas Appeal}

SIR,-It is symptomatic of an inflationary situation that at the very time when most people are having to tighten their belts a charity is faced with asking for even greater support.

Christmas will soon be upon us and, as in previous years, the Royal Medical Benovolent Fund will be sending Christmas gifts to many beneficiaries. Most of those we help have little enough left over to buy those extras which are so much part of Christmas - this year they will have even less. The purchase of a small present for a friend or relative, the cost of providing traditional Christmas day fare and gifts for the children are in many cases expenses which our beneficiaries will find increasing difficulties in meeting.

May I therefore, Sir, through your columns, ask all members of the profession to remember those less fortunate amongst their colleagues, their families and widows,

\section{Points from Letters}

\section{Malabsorption in Overland Travellers} to India

Dr. A. Pines (Hertford) writes: Dr. S. Margaret Farquharson's advocacy of metronidazole in this syndrome (24 August, p. 519). I was in a party of six climbing in the Afghan Hindu-Kush mountains. . . Despite strict hygienic precautions we all developed episodic diarrhoea with intermittent malaise and cramps, frequent bulky stools between diarrhoea, and weight lossthree lost up to $15 \mathrm{~kg}$. Courses of sulphonamide and tetracycline had little effect. In the sixth week a few days of metronidazole was given to each member of the party with dramatic effect and rapid return of good health. Naturally no bacteriological examination of the stools could be undertaken but giardiasis seems probable. ...

\section{Growing Up Foods}

Dr. S. BRADSHaw (Hereford) writes: I protest strongly at the appearance in the B.M.f. (14 September, facing p. 695) of an advertisement for "Nestlés Growing Up Foods," a new range to be "available only at Boots." These manufactured foods are not even to be for babies, they are a "special range of foods for pre-school children." Are we mad? Is the average mother to be regarded as no longer capable of buying, preparing, and serving the meat and two veg., the stewed fruit, the milk, the boiled egg, the porridge, the wholemeal bread and butter, the apple, the cheese and salad, and the herrings that, with a little variation, will keep any preschool child healthy? Is she instead to pay more for prepared foods, canned or bottled or packaged at a high energy cost, their nature and mode of preparation and administration decided for her by a commercial firm? Commercial interests have already very largely deprived the mothers and children of the Western world of the benefits of breast-feeding, and according to War on Want are now seeking to do the same in the underdeveloped world. ${ }^{1}$ Are we to tolerate this new extension of their nutritional empire? ...

1 Lancet, 1974, 1, 719.

\section{Domiciliary Consultations}

Dr. H. JacoBs (Severalls Hospital, Colchester) writes: I should like to take up a point in the letter from Dr. S. Mehta and others (14 September, p. 690). Domiciliary and to realize that their generosity can bring much unexpected happiness and relief to old and young alike.

Contributions may be passed direct to the treasurers or medical representatives of the local guilds of the Royal Medical Benevolent Fund or sent, marked "Christmas Appeal," to the Director, Royal Medical Benevolent Fund, 24 King's Road, Wimbledon, London SW 19 8QN.-I am, etc.,

London S. .19

T. HOLMES SELlORS

Royal Medical Benevolent Fund

consultations were not devised or arrived at as a method of augmenting the pay of those doctors who do them. They are used in Britain because they are of the very greatest value, certainly nowhere more than in psychiatry, where one can see the patient in his own setting and all the tensions or otherwise in the family, together with the social and economic environment etc. Some patients just cannot get up to clinics and so far from this country switching over to a system without home consultations, as they describe oocurs in Sweden, I would venture to suggest that Sweden might do very well to look at our system from the point of view of the patients. We must not forget that the N.H.S. is basically run for patients and a number of patients cannot or will not come up to clinics. The urgency of their situation is often such that it is imperative that they have a full examination where they are. . . .

\section{Population Problems}

Dr. S. L. Henderson SMITH (Huddersfield) writes: reports of the two recent population conferences leave one with a sense of profound disquiet at the general attitude of "laissez-faire" which the experts are taking with regard to this problem. ... The responsible and intelligent limit their families. The feckless and socially disadvantage breed as they will. Can society afford to shy away from some form of control in the near future (for example, the licensing of children beyond the second?) With effective contraception and legal abortion now available the continued production of unprepared-for children becomes a luxury whose exercise is increasingly antisocial. In an overcrowded and potentially starving world the right to breed may well need to be re-examined.

\section{Doctors' Pay}

Dr. W. J. J. LEGG (Putaruru, New Zealand) writes: I note with some satisfaction that fellow general practitioners in Britain are at last seriously threatening to quit the N.H.S. Last year I emigrated to New Zealandfar from being a rich country-and as a result have more than trebled my income so that now my earnings are in excess of $£ 20,000$ per annum-and there are plenty of G.P.s out here earning far more. Recently midwifery fees were increased by $50 \%$ and are now around the $\$ 100$ mark, of which about half is received for the confinementequivalent to $£ 30$ sterling. . . . 